\title{
Geography in Basel - The Integrative Approach
}

\author{
Hartmut Leser, Rita Schneider-Sliwa, Peter Nagel, \\ Eberhard Parlow, Christine Alewell, Basel
}

\section{Introduction}

The Department of Geography of the University of Basel views its different divisions as complementary disciplines which are committed to an integrated approach in geography. It is this philosophy which recently motivated the establishment of a new chair for Environmental Geosciences and Soil Science. At the centre of Geography at the University of Basel lies the relationship between humans and their environment, viewed from a physical and human geographical perspective, and combined with biogeographical and climatological approaches.

This article first highlights common principles of the different disciplines. This will be followed by a brief presentation of research topics - including both practical projects as well as underlying methodical and theoretical models. Finally, the integrated approach will be related to current standards of geographic theory.

\section{Conceptional and methodical principles}

Geography is the science of «human-space-environment» and is founded on two basic theories: (1) the theory of complex (holistic) geographic perspectives and (2) the theory of geographic dimensions. The former relates to reality and its complex domain which can be resolved only in research but not in reality. This has consequences on research approaches and methodologies, as well as on the results obtained and their impact. The latter also affects methodological approaches. It does not only categorize formally the so-called geographic dimensions (Bordsdorf 1999; LESER 1997; LESER \& Schneider-Sliwa 1999; NeEF 1967) but refers to them as «tools» for specific spatial research because they determine the choice of methods and thereby also the impact of the results. That the public has understood this theory, albeit rather intuitively and not resulting from theoretical reflection, is shown by the widely used terms «local», «regional», «zonal» and «global» dimensions and certainly adds to the viability of any environmental work - be it in the field of man or economy, be it in the field of nature, landscape or resources.

\section{Man-environment-research in society today}

Urban or natural landscapes are the very starting point of geography. Geography is concerned with the problems resulting from interactions between humans and the environment and hence space - which is anything but a new idea (BARrows 1923; NEEF 1969, 1979; STODDART 1965). Examples are problems related to urban ecology, urban economic and social geography, the landscape, water and nutrient balance in the soil as well as biogeographical and ecological problems related to climate change. In dealing with current problems arising from the use of physical space, basic principles for planning and environmental planning as well as for the sustainable use and protection of resources are being elaborated (Fig. 1).

Over the last two decades, the International Geographical Union (IGU) in particular stood up for integrated man-environment research, as evidenced by numerous programmes and publications. Subject-specific problems were gradually put into a larger, interdisciplinary context, as explained in «Understanding the Earth System»(EHLERS \& KraffT 2001). Even from the political viewpoint of the discipline, this approach is increasingly becoming a guiding principle, as pointed out by the Deutsche Gesellschaft für Geographie and supported in "Geographie heute - für die Welt von morgen» (EHLERS \& LESER 2002). Intended for improving public relations, both the above communicate the complexity of geographical reality. This is also reflected in the variety of authors representing completely different disciplines.

The different chapters are not only «up-to-date» in terms of focusing on man-environment problems but demonstrate that integrated, multi-disciplinary approaches - based on more complex methodologies - yield more credible results. This reiterates what has already been stated before: geography by its very nature is transdisciplinary, integrating a wide range of subject matters (LESER 2002). Another objective is to demonstrate that geographic research is concerned with real problems and conflicts arising from human-earth interactions. This implicates (1) a close relationship to practice and need for applied research and (2) rejection of the limitations of disciplinary research. Certainly, this approach responds to the needs of society - which are otherwise only partly appreciated by the scientific community, at least not in their real complexity. This lack of societal focus is reflected in the unimpeded trend towards disciplinary specialization in science. 


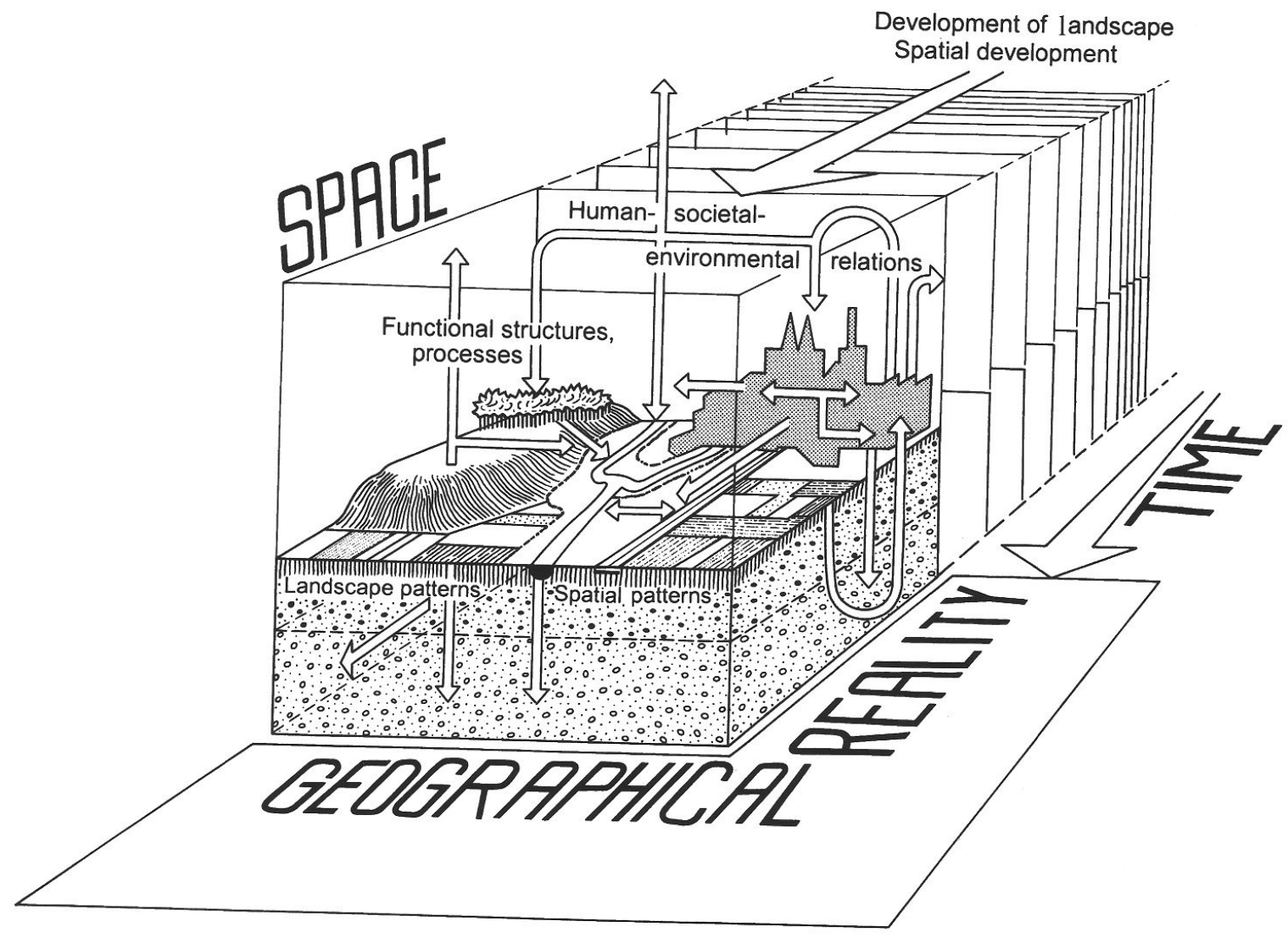

Fig. 1: The realm of geographical research Das Spektrum geographischer Forschung L'éventail de la recherche géographique Draft: H. LeSER; graphics: L. BAUMANN

\section{Human-environment research themes of the Geography Department in Basel}

The research themes and projects presented in the following provide evidence that the department feels committed to both the theoretical basis of the discipline of geography and the practical needs of the public. At the same time, they demonstrate the inherent transdisciplinary concept of geography.

\subsection{Physiogeography and landscape ecology}

Physiogeographical research is landscape ecological research (Fig. 2 and 3). This notion is founded on theoretical grounds and on the inherent scientific concept (holistic, integrative, in relation to landscape scales). Operating in an environment altered by man, this research deals with real landscapes. Two topics are presented here in order to elucidate the goals of this research: «Soil erosion and element balance in landscapes» and «Landscape change/landscape ecology».

\subsubsection{Soil erosion and element balance in landscapes}

This project represents the traditional field of Basel's physiogeography. It originally began with soil erosion research and was developed to find a suitable field method. An overview is given in the publication list of the «Research Group Soil Erosion Basel» (GeoGRAPHIC INSTITUTE BASEL, Forschungsgruppe BODENEROSION BASEL 2003). What is it about?

- The abiotic geo-ecological factors, geo-relief and soil - adapted to the geo-ecosystem model - are central issues. Soil constitutes the main subject of research, as it represents a significant component of the landscape. Emphasis is placed on physical characteristics, transfer processes and resulting turnover rates. This research is carried out in the Länenbach 


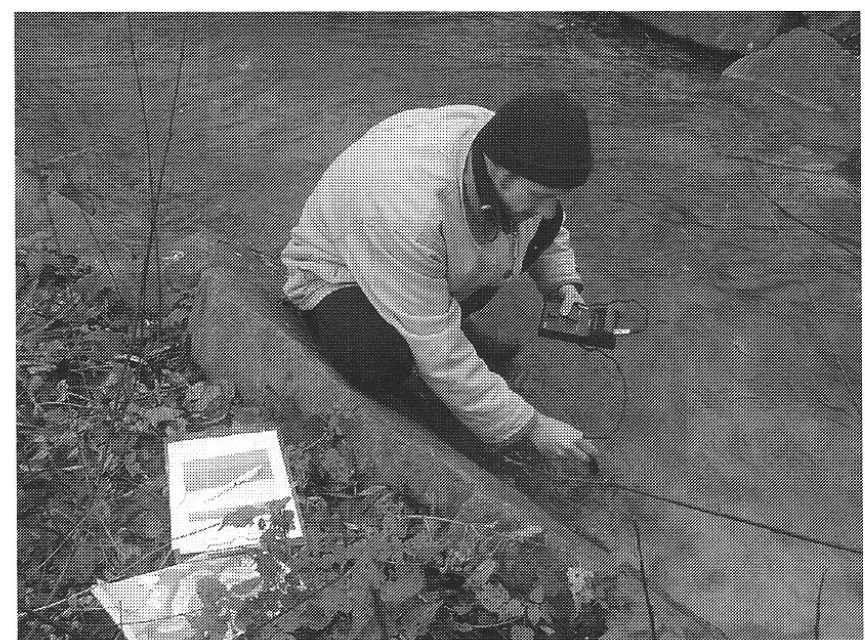

Fig. 2: Limnoecological measurements characterize the situation in the water.

Limnoökologische Messungen können die Verhältnisse in einem Gewässer charakterisieren.

Les rapports qui définissent une eau peuvent être caractérisés par des mesures limnoécologiques.

Photo: O. STUCKI

area in the municipality of Rothenfluh (Canton of Baselland). It focuses on phosphorus turnover relevant for agriculture and nutrient balances. LESER et al. (2002) gave a summary of the project (Fig. 4).

- Long-term research is carried out on permanent plots which are subject to real agricultural use. Data on element balances and erosion dynamics have been collected for about 20 years. They reflect changes in land use resulting from economic, ecological as well as political reasons. Data obtained in the field allowed for a comprehensive, comparative assessment of erosion models (Hebel 2003), revealing surprising results with respect to the validity of current models.

- The project provides a framework for a variety of individual sub-projects, lasting from a few months to several years. These sub-projects are being implemented in collaboration with different institutional and private partners from the chemical industry, federal research institutes, agricultural colleges, agricultural field stations, authorities with an environment and soil protection mandate in municipalities as well as individual farmers.

- Recent accounts of the results were presented by RüTtIMANN (2001) on the cultivation of maize, by Böнм (2003) on soil erosion in military training grounds, by HEBEL (2003) on the comparison of erosion models and by MARXER (2003) on fire ecology.

\subsubsection{Landscape ecology/landscape change}

This project group underwent many changes, which are reflected in the documentation of the literature (GEOGRAPHISCHES INSTITUT BASEL, FORSCHUNGSGRUPPE LANDSCHAFTSANALYSE UND ANGEWANDTE LANDSCHAFTSÖKOLOGIE 2003). After termination of geoecological field research in Spitzbergen and in the Alps, the development of geoecological methodology was no longer a research subject, which led to publications, such as the «Kartieranleitung Geoökologische Karte 1: 25’000» (LESER \& KLINK 1989), the «Bewertungsanleitung des Leistungsvermögens des Landschaftshaushalts» (Marks, Müller, Leser \& KlinK 1999), and the resulting «Landschaftsökologische Erfassungstandards» (ZEPP \& MüLLER 1999). Subsequently, researchers

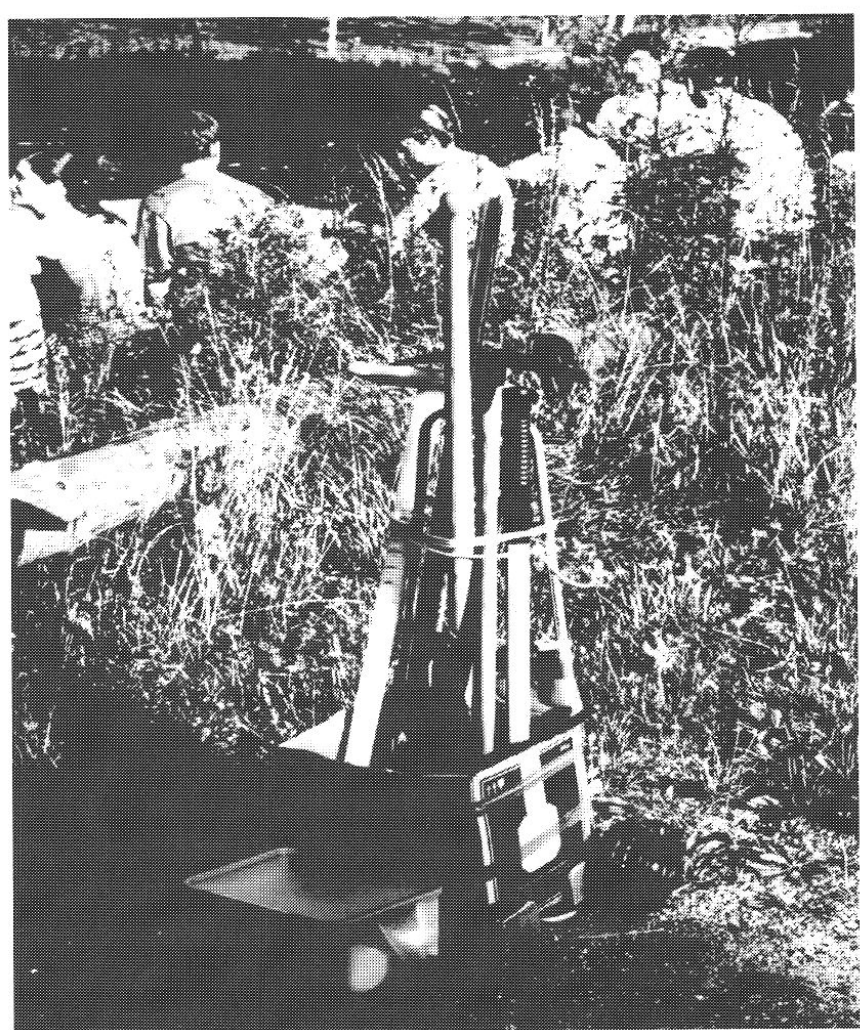

Fig. 3: Computer aided methods and simulation models do not substitute hands-on experience.

Trotz EDV und Simulationsmodellen: «Handwerk» ist im Praktikum immer noch gefragt.

En dépit du traitement informatique des données, les ordinateurs n'ont pas détrôné l'«artisanat».

Photo: H. LESER 
Scale and parameters of measurements

\section{Spot measurements}

Parameters determined by spot measurements

- Amount of eroded material

- Splash impact

- Climate elements

- Soil-water content

- Surface runoff

- Matter flux

- Intensity of simulated rainfall

\section{Monitoring of (agricultural)} fields

- Sediment sampling unit

- Sediment sampling unit at field station

- Artificial drainage discharge

- Soil water outflow

\section{Monitoring of study} areas

- Mapping of soil erosion damage

- Soil mapping

- Geomorphological mapping

- Land use mapping

- Catchment area surface runoff and outflow measurements

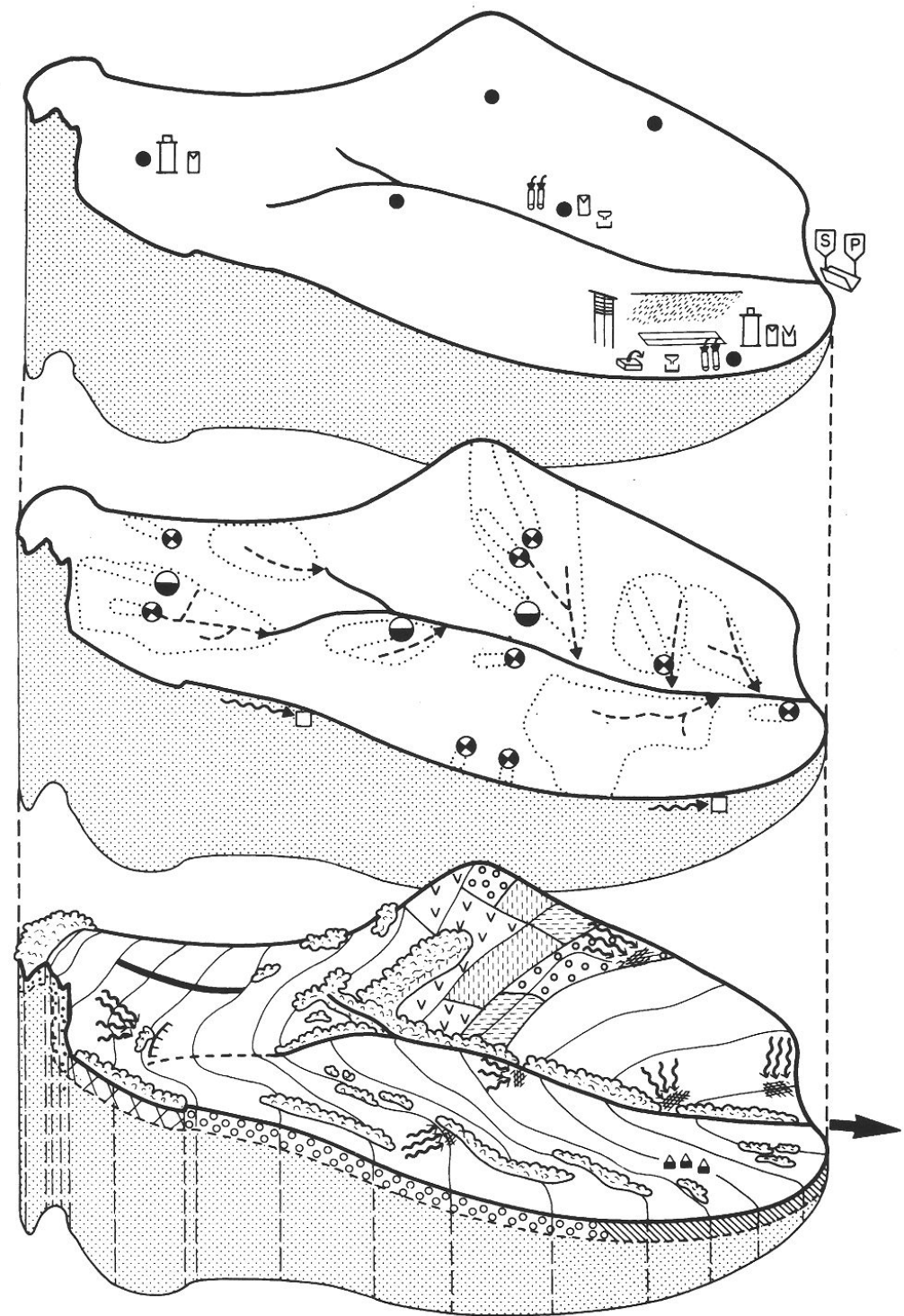

\section{$v_{v}==-7$ Land use}

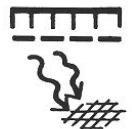

Slope curvature, position of knickpoints

Erosion form, deposition form

$\because$ Soil type, substratum

Catchment area runoff

Q.....: Sub-catchment area with sediment sampling unit

Sub-catchment area with sediment trap at field station

$\because \cdots$ : Surface catchment area with artificial subsurface drainage system

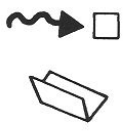

Ground-water seepage

Discharge channel

P. Measuring weir

S Self-recording water sampler
Soil erosion test plot

Rain simulation test plot

乎

Weather station

Rainfall gauge

Rainfall recorder

Rainfall gauge for chemical analysis

$\nabla \quad$ Funnel lysimeter

Soil-water sampler

Soil moisture recording point

5 Splash impact recorder 
participated in digital geoecological mapping projects (Huber 1995; Menz 2001), which were linked to soil erosion modelling (DRÄYER 1996). These projects aimed at developing landscape assessment schemes, thereby introducing a second research theme.

- This approach involves investigations of the change of cultural landscapes, viewed from a human and landscape ecological perspective (SCHNEIDER-SLIWA, Schaub \& Gerold 1999). It focuses on the integrative viewpoint of the real landscape, as put forward by EHLERS (1998). Humans stand in the centre because «nature» in the original sense (non-anthro-pogenic) hardly exists any more. Even the scientific concept of geography has been adapted to this approach.

- Issues related to the change of landscapes could have been integrated into the Swiss Priority Programme (SPP) Environment of the Swiss National Science Foundation. However, they did not come to the attention of project leaders, in particular with respect to the scale and abiotic domain of landscapes and the relationship with elements of the cultural landscapes. On the basis of the so-called Biodiversity Project, the issues were eventually raised by the project «Comparison of Element Turnover in Different Types of Landscapes» (OGermann 1999). Methodical-methodological reflections were presented by Leser \& Schaub (1995), Leser \& Nagel (1998), and - from a practical viewpoint - by LESER (1997, 2002b).

- Given that the research extended across different disciplines, the concept of transdisciplinarity was analysed as well (LeSER 2002a; POTSCHIN 2003). This research encouraged studies on landscape protection, directed towards the conservation of nature, geotopes and cultural landscapes. Many research projects are being conducted to this end, partially in collaboration with the Arbeitskreis Geoökologische Raumgliederung und Leistungsvermögen des Landschaftshaushalts.

\subsection{Human geography/urban and regional development}

Human geography research is concerned with the formation of living space by man and society and the consequences of spatial planning for man, society, the economy and environment. These can be seen most clearly in agglomerations, which are the microcosm and research laboratory of society. They are the places where human influences, social, ecological and economic problems are intensified and also where city-outskirts and urbanrural relations become blurred. The Human Geography Department in Basel has a threefold task in this field of investigation. Specifically, it aims to consolidate its strengths in areas of application and to deliver useful information for urban development policy, economic promotion, regional development in industrialized and developing nations, as well as decisions by firms - by means of regional statistical studies, target group-oriented surveys of households and businesses, market and locational analyses and field studies in areas with delays in development (Fig. 5, 6 and 7).

\subsubsection{City and agglomeration - economic and social systems in the city}

Cities are the most important living areas where one gains experience about the world population. Distribution, structure, and the dynamics of the urban population define services of the public administration as well as the provision of housing, jobs and education. Entrepreneurial decision-making is also dependent on the development of an agglomeration, the city and its districts. This research emphasis is

- dedicated towards demographic and social economic processes and structures in cities and their surrounding areas both in the local and regional context of Basel and the Southern Upper Rhine region and in metropolises worldwide. Examples for this kind of work - in connection with different cooperation partners such as the Statistical Authority of the Canton of Basel-Stadt, or the research group «Lifestyle, Social Position and Urban Structures» of the Academy for Environmental Planning and Regional Studies in Hanover, furthermore, Social Service Agencies of the Canton of Basel-Stadt are:SCHNEIDER-SLIWA et al. $(1999,2001)$, which analyses the population and economic structures and processes in Basel; EGLI (2001, 2003), which documents homelessness in Basel; EDER SANDTNER $(2001,2004)$, which reveals the new segregation patterns in Basel, using block data for the entire city; SAHLI \& SCHNEIDER-SLIWA (2004); SCHNEIDER-SLIWA 2004, which analyses the cut-off problem quarters of the African and Maghreb peoples in Strasbourg; KAMPSCHUlte \& SchNeIDER-SLIWA (1999), which choose as its central theme the image of Basel as a steering device of urban development. Various market studies analyze the

Fig. 4: Multiple-step methodical concept for the determination of soil erosion and geoecological parameters: The Riedmattbach example.

Mehrstufiges methodisches Konzept für die Bestimmung von Bodenerosion und geoökologischen Parametern: Das Beispiel des Riedmattbaches.

Un concept multiple de progression méthodique pour la détermination de l'érosion du sol et des paramètres géoécologiques. L'exemple du Riedmattbach (la rivière du Riedmatt)

Source: PrasuHn (1991) 


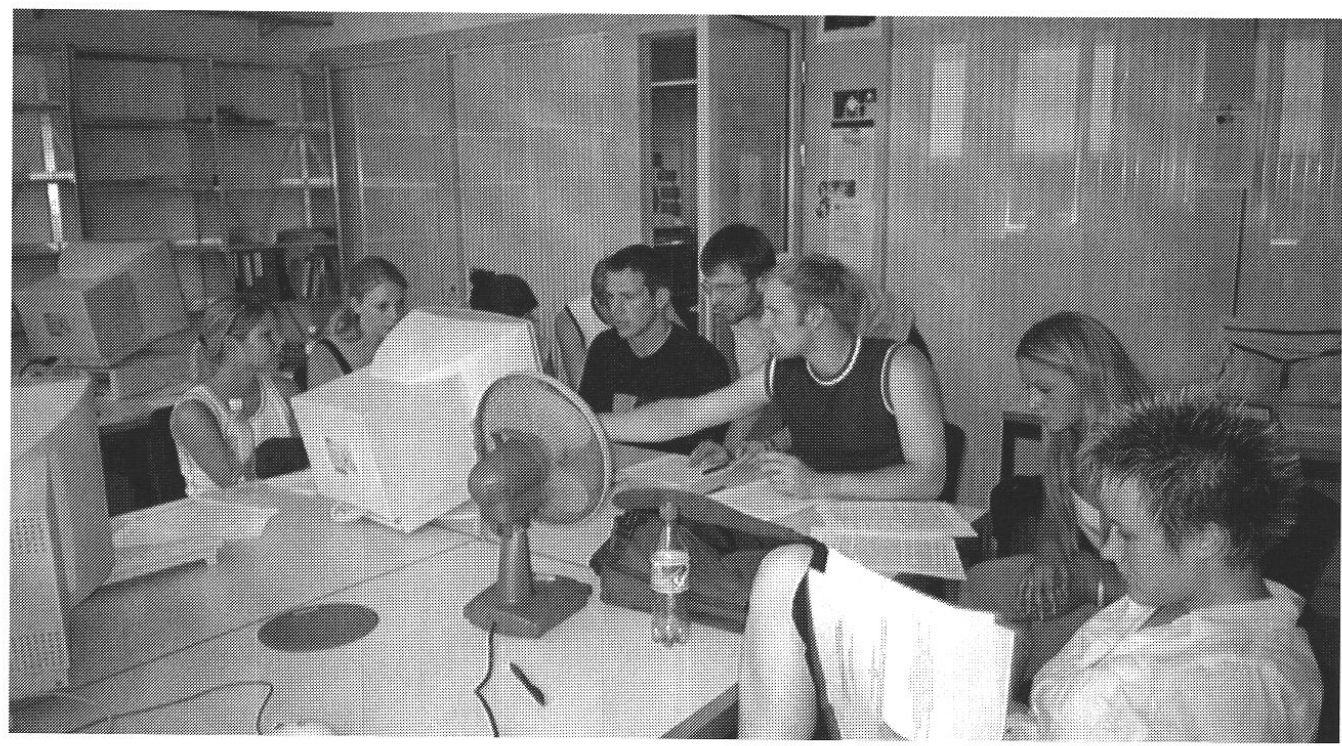

Fig. 5: Statistical analysis of large surveys, final discussion Statistische Auswertung von Grossbefragungen, Abschlussbesprechung Exploitation statistique d'enquêtes à grande échelle, discussion finale Photo: R. SCHNEIDER-SLIWA
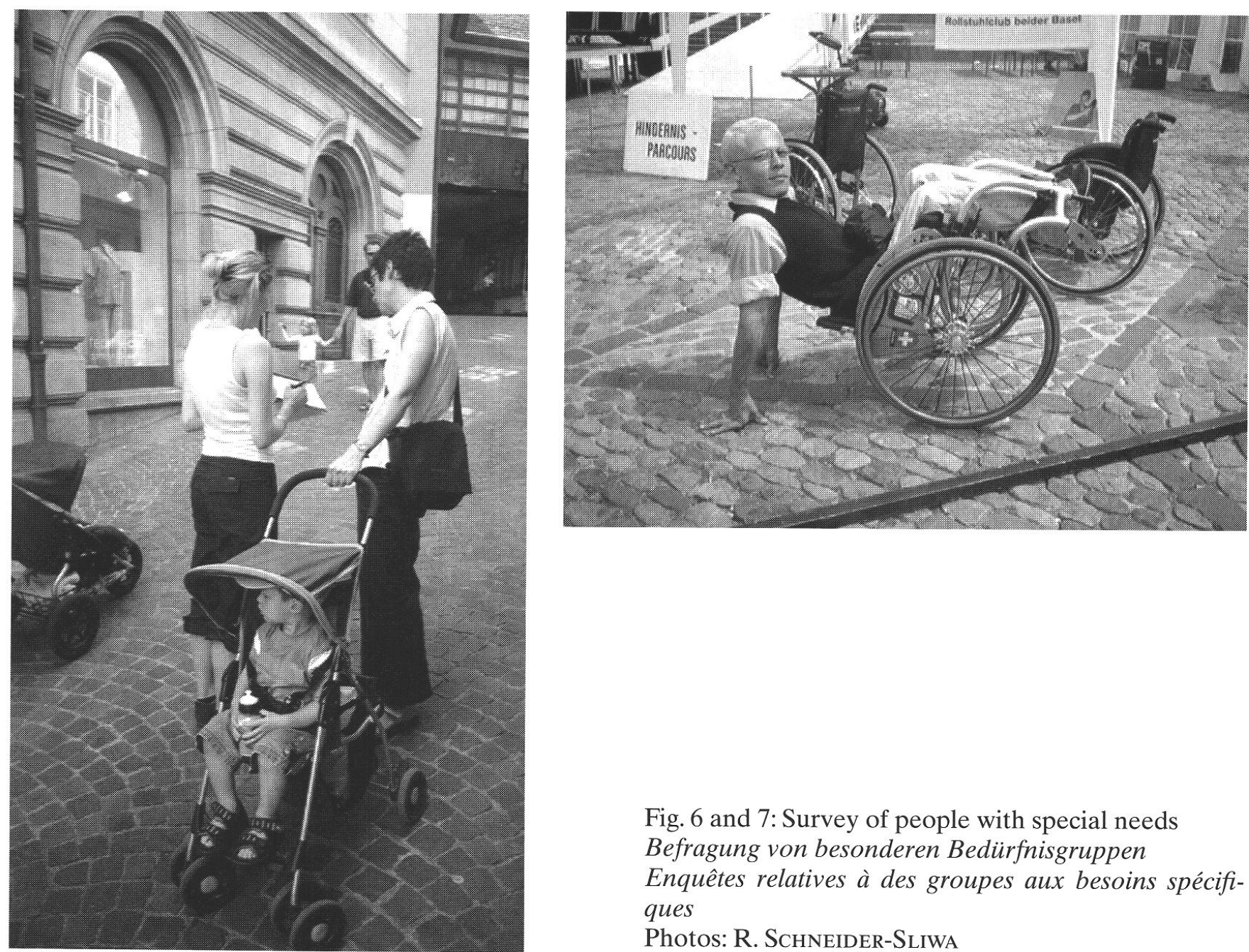

Fig. 6 and 7: Survey of people with special needs Befragung von besonderen Bedürfnisgruppen Enquêtes relatives à des groupes aux besoins spécifiques Photos: R. SCHNEIDER-SLIWA 
applicability of research to municipalities of the tri-national region of Basel, e.g. by KAMPSCHULTE, SCHNEIDER-Sliwa \& ZunZer (2002); KAMPSCHUlte \& SChNeIDER-Sliwa (2001); SchneIder-Sliwa \& Kampschulte (2002).

- As well as dedicated to international metropolises undergoing radical change: SCHNEIDER-SLIWA (2002) with the example of the globalization and restructuring of Berlin, Brussels, Hanoi, Ho-Chi-Minh City, Hong Kong, Jerusalem, Johannesburg, Moscow, St. Petersburg, Sarajevo and Vienna; BreItung \& SchNeIDER-SLIWA (1997) with the example of Hong Kong; BreItUNG (2001), who as an example of political change investigates the social spatial repercussions and regional politics in Hong Kong after 1997; BREITUNG \& SCHNEIDER-SLIwA (2000), who in the example of Berlin chose as the central theme the unified and divided city; KAMPSCHULTE (2002), who illuminated Vienna's new location between East and West.

\subsubsection{Regional economic development - interwoven relations across borders}

Globalization, technological change and efforts towards economic integration change business cycles and locational advantages and intensify regional competition. This area of work investigates

- structural changes of economic areas and the development of jobs, population and infrastructure, especially in the tri-national border region of Basel, the Southern Upper Rhine region and Northwest Switzerland, but also selected developing nations. The following individual projects are arranged here, which originated in cooperation with the Statistical Authorities of the Canton Basel City as well as other cantonal and city authorities in Basel, surrounding municipalities and in institutions of tri-national cooperation. They are concerned with the structure and dynamics of the economy in Northwest Switzerland in the context of globalization, e.g. by SchNeIDER-Sliwa et al. (2001); KAMPSCHUlte \& STRASSMANN (1999); STRASSMANN (2002); STRASSMANN, Frost \& BrunNer (2000).

- A further goal is to show the broad spectrum of regionally specific locational advantage needed for the development of a region well adapted for the future. Research on economic development across the borders carried out market studies in which approximately 12000 people were surveyed between 1996 and 2000. Studies included are: KAMPSCHUlte \& SCHNEIDER-Sliwa (2001); KAMPSCHUlte, SChNeIder-Sliwa \& ZunZer (2002); SchneiderSliwa (2003a); Schneider-Sliwa \& Kampschulte (2002). The projects by EDER \& SANDTNER (2000) and EDER SANDTNER \& SANDTNER (2002) concentrated on the development of a regional identity in the common economic area of the Upper Rhine. Border region research in other regional contexts was carried out by KAMPSCHULTE (1999a and b, 2000).

\subsubsection{Urban environment and sustainable landscape planning}

Settlements and economic growth create a cultural landscape in which the balance of the ecosystem and natural leisure areas for humans are increasingly being destroyed. This area of work is concerned with:

- Planning, which carefully and sustainingly manages the scarce resources of the environment in the city and regions

- Discerning an appropriate urban environment and development planning for target groups, the acceptance of environmental protection and urban planning measures among the population and open space planning and the development of a wholesome city, which does justice to all groups in society. Two projects are mentioned here:

- In «Urban Environment in Old Age» (SchNeIDER-SLIWA 2003c), in preparation for a planning model focussing on the elderly, a survey of around 7000 people between 60 and 85 , investigated senior citizen needs and requirements for alternative living forms.

- In the project, «Road surfaces meeting the requirements of the handicapped» (SCHNEIDERSLIWA 2003b), a study on inner city paving is being carried out, the results of which will allow for a paving which not only meets the requirements of the handicapped but is also ecological and aesthetical.

\subsection{Biogeography}

The Institute for the Conservation of Nature, Landscape and Environment / Biogeography operates on the interface between geography and biology - both in teaching and basic and applied research. Its research focus is on the spatial analysis and evaluation of landscapes, using organisms as indicators. The causes for spatial patterns of biodiversity are a central theme within this research (bioindication, biomonitoring, state and dynamics of species distributions). Further topics include environmental risk assessment and environmental management. The overall goal of the applied research is to develop and promote strategies for the sustainable development and use of landscapes and natural resources.

\subsubsection{Ecology and protection of running waters}

River engineering, land use in catchment areas and chemical pollution affect the composition and dynamics of aquatic communities. Therefore, communities can be used as indicators of the ecological state of aquatic ecosystems. Our current research focuses on springs of the Regio Basiliensis and aims to provide improved scientific understanding of basic ecological processes. The objective is to develop practical strategies and assessment methods for headwater monitoring, restoration and management. Basic research deals with habitat specificity and colonization strategies of the fauna 
adapted to these island habitats. In an interdisciplinary and transdisciplinary approach, we classify different spring ecosystems and their characteristic fauna and flora, assess the degree of anthropogenic disturbances and evaluate possible restoration designs.

At the same time, techniques are being evaluated on how to exploit sources in a sustainable way for the provision of drinking water without compromising their potential as habitats for the flora and fauna. Experience in Basel has shown that it is possible to create ecologically valuable landscapes in close proximity of urban areas by forming a mosaic of semi-natural floodplains and man-made ground water enrichment sites for drinking water production. Faunal studies here provided clear evidence of a functional similarity among semi-natural and man-made habitats. Furthermore, studies on the purification of percolating water and ground water transport provided basic data for early warning systems to detect reductions in drinking water quality. Other research topics include the faunistics and ecology of groundwater fauna, biomonitoring of water quality and appraisals of river restorations.

Selected literature: Baltes \& NAgel (1997); Mersch et al. (1996); NAgel (1999); NAgel \& Baltes (1997); RÜETSCHI et al. (2001).

\subsubsection{Urban ecology and the conservation of nature, landscape and environment in cultural land- scapes}

Settlements and cultural landscapes are designed according to the social and economic activities of man. Our research aims to identify and analyse ecological and spatial characteristics of these areas and to apply this knowledge in designing strategies for an environmentally sound and ecologically sustainable urban and rural development. The principal goal is to incorporate environmental protection objectives into the structural and functional design and development of urban and cultural landscapes. Questions about nature conservation in settlement areas are just as much at the centre of attention as is basic research with feral pigeons as bioindicators of environmental pollution.

Further topics in this field of research include bioindication of anthropogenic, semi-natural habitats, using ground beetles, and the analysis of ecological functions of roof top gardens, in particular with respect to their role as surrogate habitats and migration corridors for invertebrates. In an interdisciplinary and transdisciplinary approach, the greens in urban areas are assessed in regard to their different functions, and strategies are developed for the sustainable preservation of their ecological functions.

Selected literature: KAupP (1999); LenzIN et al. (2001); LuKa et al. (1997); Nagel (1999, 2000); NAgel et al. (1998, 2001).

\subsubsection{Tropical resources management and development cooperation}

Our research emphasis is on the ecological analysis and assessment of human impacts on subtropical and tropical landscape ecosystems and - in a national and international co-operation context - on the development of environmentally sound resource utilization strategies. Our work in this area at present focuses on various countries in inner tropical Africa (Fig. 8).

At the core are the development of environmentally friendly and sustainable methods and strategies for safeguarding agricultural production. Our research concentrates especially on ecological side-effects of classical, traditional, and more recently, biological and genetic control techniques against pests of crops and vectors of human and livestock diseases.

A second important research area is the development of adapted conservation strategies. This research focuses on the fragmentation of rain forest fauna. It evaluates possibilities to reduce fragmentation by creating networks of alternative habitats such as certain plantation forests. The effectiveness of different species protection strategies is investigated, using a range of different indicator groups (wood-dwelling beetles, detritivorous invertebrates, primates). This research combines metapopulation models and molecular genetic analysis. Another project studies spatial and behavioural adaptations of larger game (antelopes, buffaloes, elephants) to annual savannah fires.

Selected literature: Nagel (1995); Peveling \& Nagel (2001); Peveling et al. (2003a); Peveling et al. (2003b); Specht (2002); Stolz et al. (2002).

\subsubsection{Zoogeography and systematics}

The spatial analysis of species distribution patterns is an instrument of biogeographical research. Phylogenetic and systematic studies of selected animal groups and analyses of their present and past distribution are at the core of this research. These studies not only provide basic biogeographical data but contribute also to the reconstruction and forecast of landscape dynamics as well as to species and landscape conservation programmes. The research groups focus on the zoogeography and systematics of the following taxa: carabidaepaussinae (worldwide), cicadas (selected European taxa) and ants (especially Neotropis). For behavioural and ecological studies under laboratory conditions, rearing facilities have been established for some of these taxa. At present, molecular genetic methods are being used mainly to reconstruct the formation of relict distribution areas of carabids. The ecology of terrestrial island biotopes is being investigated, using the examples of central European scree slope ecosystems. 


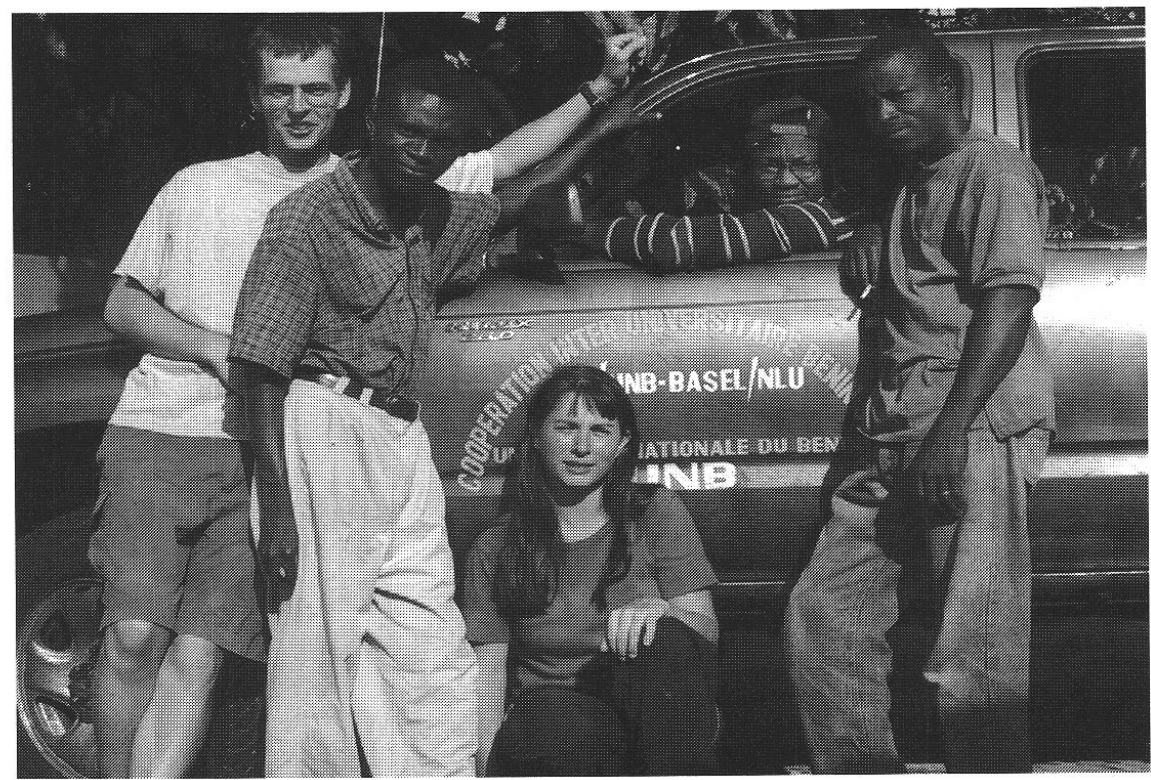

Fig. 8: Some staff members of the project on «Conservation of biodiversity in Lama forest, Benin» in the field in May 2001.

The research is funded by the Swiss Agency for Development and Cooperation and the Swiss National Science Foundation. It is organized as a research partnership between the Faculty of Agricultural Sciences of the University Abomey-Calavi, Benin, and the Institute for Environmental Sciences/Biogeography of the University of Basel.

Teammitglieder des SNF- und DEZA-unterstützten Forschungprojekts «Nachhaltige Bewahrung der Biodiversität im Lamawald, Benin» im Gelände in Süd-Benin im Mai 2001.

Quelques représentants du projet "Conservation de la biodiversité de la forêt de Lama, Benin», sur le terrain en mai 2001.

Photo: R. PEVELING

Selected literature: De Andrade \& Baroni Urbani (1999); Giulio di et al. (2003); MöSEler \& Molenda (1999); MüHLETHALeR \& NAGel (2001); NAGel (1997).

\subsection{Meteorology and remote sensing}

The scientific formulation of questions at the Institute for Meteorology, Climatology and Remote Sensing concentrates on the topics of experimental micrometeorology; topoclimatological differentiation of the landscape and the conversion of these results for urban and regional planning; the use of satellite data and numerical models for spatial analysis of meteorological fields, especially radiation and heat fluxes; as well as the implementation of a numerical model for weather forecasting, whereby short term forecasts (now-casting) is prevalent (Fig. 9).

\subsubsection{Experimental micrometeorology}

Experimental micrometeorology investigates the exchange of water, heat and carbon dioxide on different surfaces on the interface between the earth's surface and the atmosphere. Meteorology Basel is represented in international projects in various climate zones of the Earth. Naturally, the region of
Basel plays a dominant role in the research projects. However, projects in the Alps, in the Mediterranean region, in Northern Scandinavia, in the Spitzbergen Island and California are also carried out. The formulation of questions covers a wide spectrum, ranging from the diffusion of harmful substances over cities and the examination of the turbulent heat exchanges to questions on water use for agriculture in arid regions of the Mediterranean and the energetic conditions, which produce extreme instances of snowmelts (slush flows) in Polar Regions.

References: FeIgenwinter (2000); Vogt \& FeigenwinTER (2000); Bernhofer \& Vogt (2000); FeigenNinter et al. (2000); Gude et al. (2000); Feigenwinter et al. (1999); Gude \& Scherer (1999); Parlow (1998b); Scherer et al. (1998); Gude \& SCHERER (1998); JäGGI (2002); ArcK \& Scherer (2002); van Gorsel et al. (2003).

\subsubsection{Models for reality}

Numerical models allow for the computer-aided simulation of the processes in the atmosphere and the exchange processes between the Earth's surface, veg- 


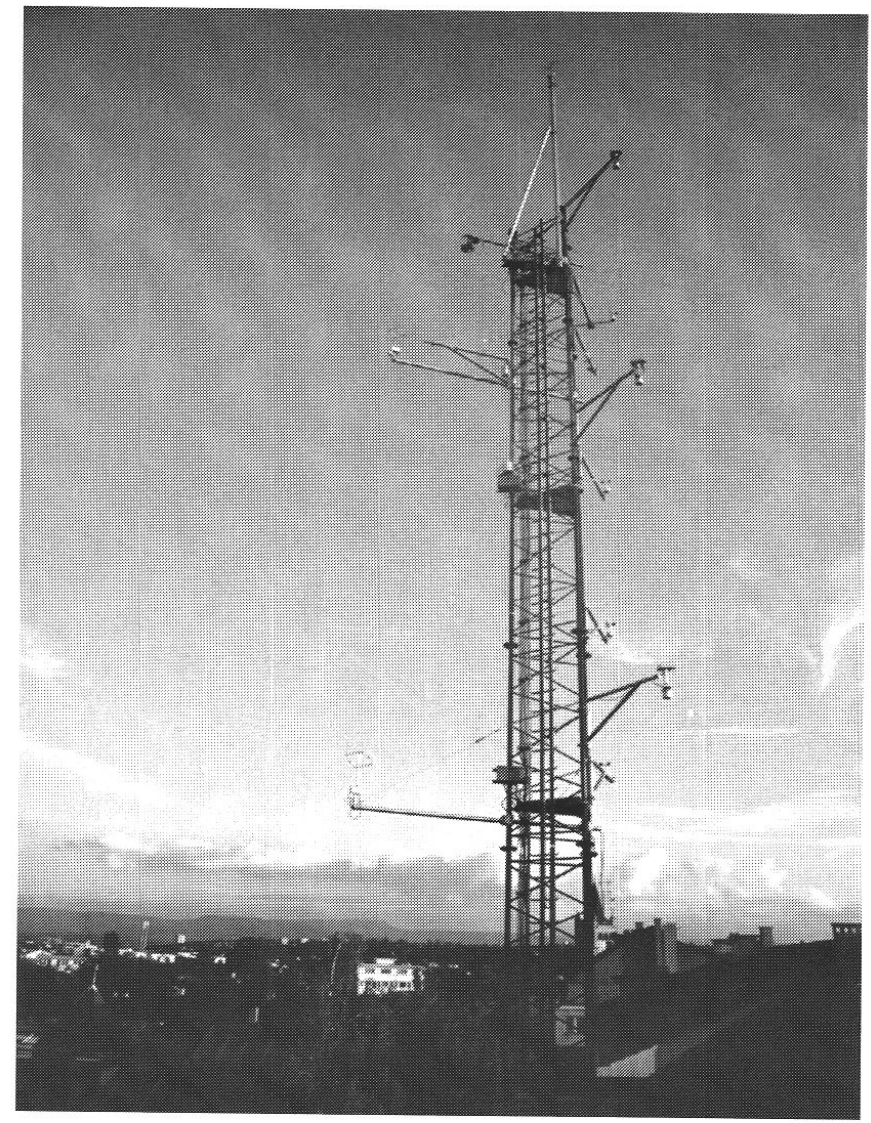

Fig. 9: Meteorological tower for urban climate studies in the city of Basel

Mess-Turm für Stadtklimauntersuchungen in der Basler Innenstadt

Tour météorologique pour analyses climatiques urbaines à Bâle

Photo: MCR Lab

etation and the atmosphere. Mesoscale models calculate the consequences of topography and land use on the atmosphere and help to make assessments on local effects for weather forecasts, traffic safety and planning. Real time models for the whole of Europe and high-resolution forecasts for the region of northwestern Switzerland are calculated on a daily basis at the University of Basel and published on the Internet at (www.unibas.ch/geo/wetter). Local effects, such as the Möhlin Jet, which in winter leads to the dissolution of fog in the region of Basel, can be modeled and studied on the computer. By means of the following projects: REKLIP (Regio-Klimaprojekt), KABA (Klimaanalyse beider Basel) and CAMPAS (Klimaanlayse des Kantons Solothurn), many years of experience in the application oriented evaluation of measurement data, model calculations and satellite data, especially for urban and regional planning, exists.
Selected literature: FEHRENBACH et al. (2001); FEHRENBACH \& SCHERER (2000); SCHERER et al. (1999); FEHRENBACH (1999).

\subsubsection{Remote sensing}

Remote sensing is the measurement and observation of the Earth's surface and the atmosphere without contact (Fig. 10). It can be carried out from the ground or with the aid of airplanes and satellites and delivers surface covering measurements on varying spatial and temporal scales. The University of Basel participates in various national and international remote-sensing projects, which stretch from the high Arctic Circle over the Alpine region to subtropical regions and are concerned mainly with radiation and heat balances. The European Space Agency (ESA) is an important project partner. In combination with micrometeorology, which works with individual measurement locations, spatially differentiated statements about heat fluxes in consideration of relief and land use effects are possible. Urban climatology is of great importance. Satellite systems, which are used most frequently, are the LANDSAT-ETM and ASTER, which possess spatial resolutions up to $15 \mathrm{~m}$ in various spectral ranges (NOAA-AVHRR and MODIS, as well as microwave systems such as ERS-1/2 and ENVISAT).

References: PARlow (2000a); PARlow (2000b); Scherer et al. (2000); PARLow (1998a), PARlow (2003).

\subsection{Environmental geosciences and soil science 4.5.1 General directions}

In January 2004, a new institute for Environmental Geosciences and Soil Sciences is planned to be opened. The focus of the research group will be on interdisciplinary geoscientific research. The goal is to understand and to assess the context of ecosystems in the lithosphere, pedosphere, atmosphere, hydrosphere, biosphere and anthroposphere (Fig. 11).

Only if the function and interaction of these different spheres is understood, can the environment be protected from disturbance and human impact. Thus, the research group will concentrate in particular on the pedosphere, with special attention being paid to the coupling and interaction between the cycles of elements (carbon, nitrogen, sulfate, nutrients) in seminatural ecosystems.

Within this area, the focus will be on changes in the cycles of elements but also on changes regarding the coupling of these cycles due to altered climate and environmental conditions. It is, for example, largely unknown how mineralization rates of sulphate and nitrogen react to a decrease in anthropogenic deposition with a concurrent change of climate. A change in the mineralization rates, however, generally exerts 


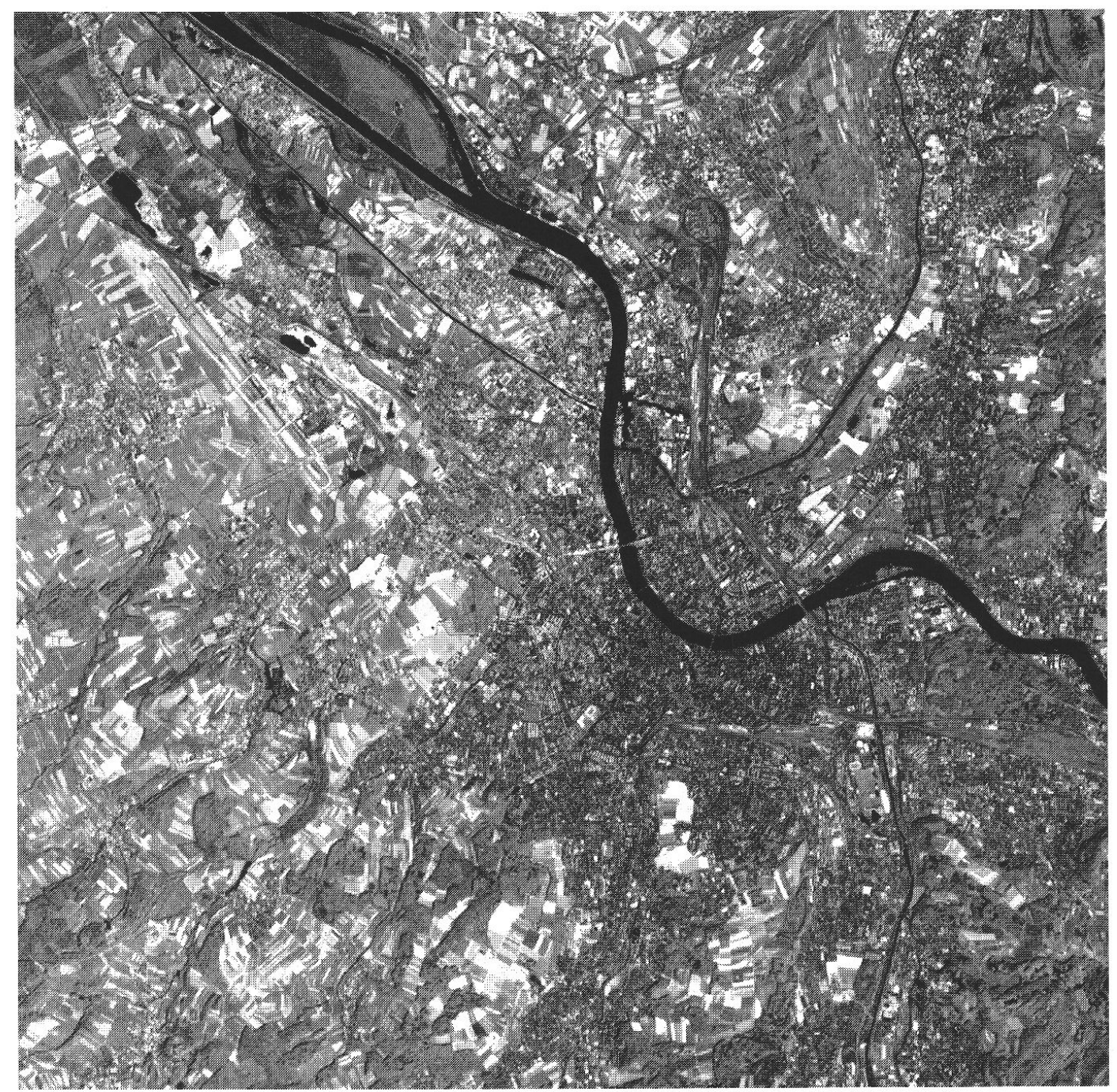

Fig. 10: Aster satellite image of Basel Aster-Satellitenbild von Basel

Image satellite Aster de Bâle

great influence generally on substance balances and on phenomena such as nitrogen saturation of ecosystems, reversibility of water acidification, or the buffer capacity of the soil. An important aspect will also be the restoration of ecosystems - especially soil remediation.

Selected literature: Alewell, Mitchell, Likens \& Krouse (2000); Alewell, Madnerscheid, MeesenBURG \& BitTersohl (2000); Alewell (2001); Alewell 2002.

\subsubsection{Methods}

Besides general biogeochemical methods and analysis, an important tool will be that used for the investigation of stable isotopes $\left({ }^{15} \mathrm{~N},{ }^{18} \mathrm{O},{ }^{34} \mathrm{~S},{ }^{13} \mathrm{C}\right)$. The emphasis in this area will be on field investigations, because the transference of results from laboratory experiments to real situations is only possible on a limited scale.

Regarding methodology, the Environmental Geosciences and Soil Sciences research group aims towards interdisciplinary cooperation. Only by using a combination of methods (e.g. results from biogeochemical analysis, stable isotope data and modelling) will it be possible to describe the complex behaviour of ecosystems as well as the complex course of events that take place in the soil.

Selected literature: Alewell, Mitchell, Likens \& Krouse (1999); Alewell \& Manderscheid (1998); Alewell, Lischeid, Hell \& Manderscheid (2003); Alewell \& Gehre (1999); Alewell \& Novak (2001). 


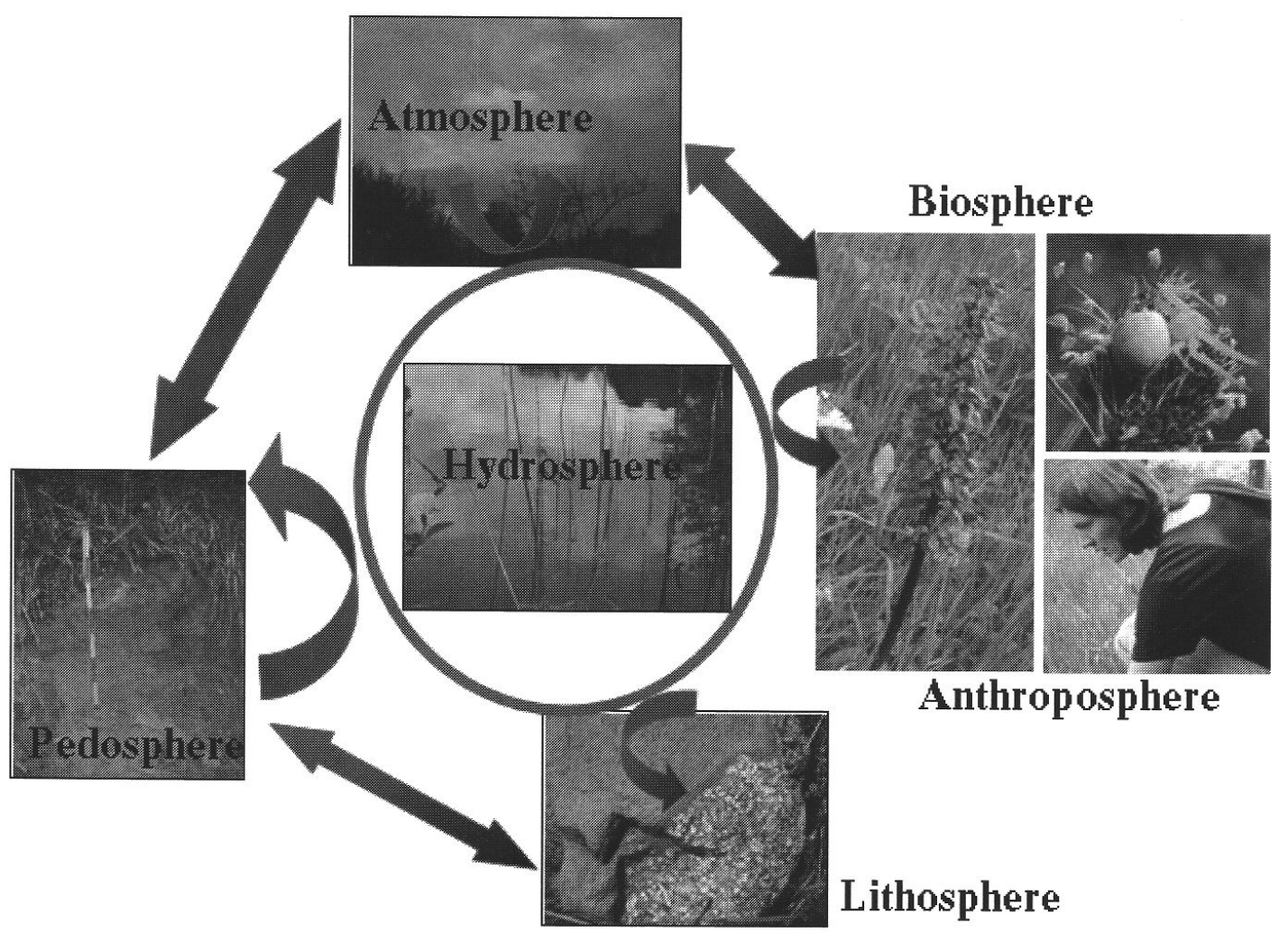

Fig. 11: Visual representation of environmental geoscience Visuelle Definition der Umweltgeowissenschaften Définition visuelle des géosciences environnementales

\section{References}

Alewell, C. (2001): Predicting reversitility of acidification:The European Sulfur Story. - In: Water Air Soil Pollut. 130: 1271-1276.

Alewell, C. (2002): Acid input into the soils by acid rain. - In: Zed Rengel (ed.): Handbook of Soil Acidity. - New York: Marcel Dekker Inc.

Alewell, C. \& M. Gehre (1999): Patterns of stable S isotopes in a forested catchment as indicators for biological S turnover. - In: Biogeochemistry 47: 319-333. Alewell, C., Lischeid, G., Hell, U. \& B. ManderSCHEID (2003): High temporal resolution of ion fluxes in semi natural ecosystems - Gain of information or waste of resources? - In: Biogeochemistry (in press). Alewell, C. \& B. Manderscheid (1998): Use of objective criteria for the assessment of biogeochemical ecosystem models. - In: Ecol. Modell. 107: 213-224.

Alewell, C., Manderscheid, B., Meesenburg, H. \& J. BITTERSOHL (2000): Is acidification still an ecological threat? - In: Nature 407: 856-857.

Alewell, C., Mitchell, M., Likens, G.E. \& R.H. Krouse (1999): Sources of stream sulfate at the Hubbard Brook Experimental Forest: Long-term analyses using stable isotopes. - In: Biogeochemistry 44: 281-299.

Alewell, C., Mitchell, M., Likens, G.E. \& R.H. Krouse (2000): Assessing the origin of sulfate deposition at the Hubbard Brook Experimental Forest. - In: J. Environ. Qual. 29: 750-767.

Alewell, C. \& M. NovaK (2001): Spotting zones of dissimilatory sulfate reduction in a forested catchment: The ${ }^{34} \mathrm{~S}-{ }^{35} \mathrm{~S}$ approach. - In: Environ. Pollut. 112: 369-377.

Arck, M. \& D. Scherer (2002): Problems in the determination of sensible heat flux over snow. - In: Geografiska Annaler, Series A, N 3-4: 157-169.

Baltes, B. \& P. Nagel (1997): Der Einfluß der Gewässerversauerung auf die Rhithral-Biozönosen im nördlichen Saarland. - Tagungsbericht 1996 der Deutschen Gesellschaft für Limnologie (DGL) und der deutschen und österreichischen Sektion der Societas Internationalis Limnologiae (SIL), Schwedt / Oder, 16. bis 20. September 1996, Band 2, Krefeld: Eigenverlag der DGL: 567-571.

BARrows, H.H. (1923): Geography as Human Ecology. - In: Annals of the Association of American Geographers 13: 1-14.

Bernhofer, C. \& R. Vogt (2000): Energy balance closure gaps - a methodical problem of eddy covariance measurements? - In: DE DeAR, R.J., Kalma, J.D., OKe, 
T.R. \& A. Auliciems (eds): Biometeorology and urban climatology at the turn of the millennium. - Selected papers from the conference ICB-ICUC'99, WMO/TD No. 1026: 199-204.

BöHM, A. (2003): Bodenerosion und Erosionsschutzmaßnahmen auf militärischen Liegenschaften am Fallbeispiel US-Truppenübungsplatz Hohenfels, Deutschland. - Physiogeographica, Basler Beiträge zur Physiogeographie 31.

BORSDORF, A. (1999): Geographisch denken und wissenschaftlich arbeiten. Eine Einführung in die Geographie und in Studientechniken. - Perthes GeographieKolleg, Gotha, Stuttgart: Klett-Perthes.

Breitung, W. \& R. Schneider-Sliwa (1997): Hongkong vor neuen Herausforderungen - Eine Global City im Wandel. - In: Geographische Rundschau 7-8: 441-449.

Breitung, W. (2001): Hongkong und der Integrationsprozess. Räumliche Strukturen und planerische Konzepte in Hongkong. - = Basler Beiträge zur Geographie 48, Wepf \& CO., Basel.

BreItung, W. (2002): Hongkong:Die Globalstadt Chinas. - In: SCHNEIDER-Sliwa, R.: Städte im Umbruch - Globalisierung und Geographie in der Neustrukturierung von Berlin, Brüssel, Hanoi, Ho-Chi-Minh-Stadt, Hongkong, Jerusalem, Johannesburg, Moskau, St. Petersburg, Sarajewo und Wien. - Berlin: Reimer Verlag.

Breitung, W. \& R. Schneider-Sliwa (2000): Das Neue Berlin - vereinigte Stadt, gespaltene Stadt. - In: Petermanns Geographische Mitteilungen 144, 5: 6-17.

Breitung W. (1999): The End of «Made in Hong Kong»? - Deindustrialisation and Industrial Promotion Policy in Hong Kong. - In: Geographica Helvetica 54, 4: 242-251.

De Andrade, M. \& C. Baroni Urbani (1999): Diversity and adaptation in the ant genus Cephalotes, past and present (Hymenoptera, Formicidae). $-=$ Stuttgarter Beiträge zur Naturkunde, Serie B (Geologie und Paläontologie), Nr. 271, 889 pp.

DrÄYER, D. (1996): GIS-gestützte Bodenerosionsmodel-lierung im Nordwestschweizer Tafeljura - Erosionsschadenskartierungen und Modellergebnisse. - = Phy-siogeographica, Basler Beiträge zur Physiogeographie 22, Basel, 1-234.

Eder SANDTner, S. (2001): Städtische Sozialstrukturen und residentielle Segregationsmuster. - In: Geographica Helvetica 56, 4: 234-248.

EDER, S. \& M. SANDTNER (2000): Staatsgrenzen in der Tri-Rhena - Barriere oder Stimulus? - In: Regio Basiliensis 41: 15-26.

Eder SANDTner, S. \& M. SANDTNer (2002): Regionale Identität über die Grenzen? Die TriRhena im Bewusstsein der Bevölkerung. - In: Revue Géographie de l'Est 1. Eder SANDTneR, S. \& R. Schneider-Sliwa (2004): Fracture sociale dans la cité de Bâle - Approche méthodologique de la ségrégation. - = Bulletin, Association de Géographes Français (in press).
EgLI, R. (2001): Obdachlosigkeit in Basel. Charakteristik der betroffenen Gruppe. Ausmass und Entwicklung, räumliche Aspekte, Trends. - In: Regio Basiliensis 42, 2: 189-198.

EgLI, R. (2003): Les Sans domicile fixe et l'aide sociale à Bâle.-Bulletin, Association de Géographes Français, (in press).

EHLERS, E. (1998): Geographie als Umweltwissenschaft. - In: DIE ERDE 129, 4: 333-349.

EHLERS, E. (2000): Globale Umweltforschung und Geographie - ein «State-of-the-art»-Bericht. - In:Petermanns Geographische Mitteilungen 144, 2: 58-65.

EhLERS E. \& T. KraffT (eds) (2001): Understanding the Earth System. Compartments, Processes and Interactions. - Berlin, Heidelberg, New York: Springer Verlag: $1-290$

Ehlers E. \& H. LeSER (Hrsg.) (2002): Geographie heute - für die Welt von morgen. - Perthes GeographieKolleg, Gotha: Klett-Perthes: 1-176.

FeHRENBACH, U. (1999): Analyse und Bewertung lokalund regionalklimatisch wirksamer Faktoren in der Region Basel. - Basel: stratus 6, 177 pp.

Fehrenbach, U. \& D. Scherer (2000): Consequences of spatial resolution transformations for land-use classification. - In: CaSANova, J.L.: Remote Sensing in the $21^{\text {st }}$ Century: Economic and Environmental Applications. - Rotterdam: Balkema Publishers: 113-117.

Fehrenbach, U., Scherer, D. \& E. Parlow (2001): Automated Classification of Planning Objectives for the Consideration of Climate and Air Quality in Urban and Regional Planning for the Example of the Region of Basel/Switzerland. - Atmospheric Environment 35, 5605-5615.

Feigenwinter, C. (2000): The Vertical Structure of Turbulence above an Urban Canopy. - Stratus 7, Basel, $76 \mathrm{pp}$.

Feigenwinter, C., Vogt, R. \& E. Parlow (1999): Vertical structure of selected turbulence characteristics above an urban canopy. - In: Theoretical and Applied Climatology 62: 51-63.

Feigenwinter, C., Vogt, R. \& E. Parlow (2000): Analysis of organized structures in urban turbulence. - In: de Dear, R.J., Kalma, J.D., Oke, T.R. \& A. Auliciems (eds): Biometeorology and urban climatology at the turn of the millennium. - Selected papers from the conference ICB-ICUC'99, WMO/TD No. 1026: 565-570.

Geographisches Institut UnIVERSITÄt BASEL, ForSCHUNGSGRUPPE BodenEROSION BASEL (2003): Verzeichnis der Arbeiten 1974-2003 (Stand März 2003). Basel, 1-16 (mimeographed; cf. http://www.unibas.ch/ geo/physiogeo/).

Geographisches Institut Universität Basel, ForSCHUNGSGRUPPE LANDSCHAFTSANALYSE UND ANGEWANDTE LANDSCHAFTSÖKOLOGIE (2003): Verzeichnis der Arbeiten 1974-2003 (Stand März 2003). Basel, 1-15 (mimeographed; cf. http://www.unibas.ch/geo/ physiogeo/). 
Giulio, A. Di, Fattorini, S., Kaupp, A., Vigna Taglianti, A. \& P. NAGel (2003): Review of competing hypotheses of phylogenetic relationships of Paussinae (Coleoptera: Carabidae) based on larval characters. - Systematic Entomology 28:1-31.

Gude, M. \& D. SCherer (1998): Snowmelt and slushflows: hydrological and hazard implications. - In: Annals of Glaciology 26: 381-384.

Gude, M. \& D. Scherer (1999): Atmospheric triggering and geomorphic significance of fluvial events in high-latitude regions. - In: Zeitschrift f. Geomorphologie, N.F., Suppl.-Bd. 115: 87-111.

Gude, M., Jonasson, C., Dietrich, S. \& D. Scherer (2000): Assessment of variability in fluvial sediment transfers in Kärkevagge (N-Sweden) during the last 50 years. - In: Nordic Hydrology 31, 4/5: 373-384.

Hebel, B. (2003): Validierung numerischer Erosionsmodelle in Einzelhang- und Einzugsgebietsdimension. - Physiogeographica, Basler Beiträge zur Physiogeographie 32, Basel.

Huber, M. (1995): The Digital Geoecological Map. Concepts, GIS methods and case studies. - Physiogeographica, Basler Beiträge zur Physiogeographie 20, Basel,1-144.

JäGGI, M. (2002): Mikrometeorologische Bestimmung des Energiehaushaltes einer Magerwiese in komplexem Gelände. - Stratus 8, Basel, 117 pp.

Kampschulte, A. (1999a): Grenzen und Systeme - Von geschlossenen zu offenen Grenzen? Eine exemplarische Analyse der grenzüberschreitenden Verflechtungen im österreichisch-ungarischen Grenzraum. Tübinger Geographische Studien 127, Tübingen.

Kampschulte, A. (1999b):The Austro-Hungarian border region - opportunities for and perspectives of regional development. - In: KnipPenberg, H. \& J. Markusse (eds): Nationalising and Denationalising European Border Regions - 1800-2000: Views from Geography and History. - Geo Journal Library 53: 173-197.

Kampschulte, A. (2000): Regionale Dimensionen der wirtschaftlichen und gesellschaftlichen Transformation in Ungarn. - In: FASSL, H. \& C. WAACK (Hrsg.): Regionen im östlichen Europa - Kontinuitäten, Zäsuren und Perspektiven. - Tübinger Geographische Studien 128, 57-73. Kampschulte, A. (2002): Wien - Neupositionierung zwischen Ost und West. - In: SchNeider-SLIWA, R.: Städte im Umbruch - Globalisierung und Geographie in der Neustrukturierung von Berlin, Brüssel, Hanoi, Ho-Chi-Minh-Stadt, Hongkong, Jerusalem, Johannesburg, Moskau, St. Petersburg, Sarajewo und Wien. Berlin: Reimer Verlag.

Kampschulte, A. \& R. Schneider-Sliwa (1999): Das Image von Basel - Steuerungsinstrument für die Stadtentwicklung? - Basler Feldbuch 16, Basel.

KAMPSChUlte, A. \& R. SchneIder-Sliwa (2001): Innenstadt- und Kurortentwicklung Bad Säckingen. - Basler Stadt- und Regionalforschung 20,64 S.

Kampschulte, A., Schneider-Sliwa, R. \& D. Zunzer (2002): Aspekte der Stadtentwicklung in Bad Säckin- gen: Ergebnisse nutzerorientierter Befragungen zu den Themen Jugend, Verkehr und «Lebensader Wasser». Basler Stadt- und Regionalforschung 21, Basel.

Kampschulte, A. \& R. Strassmann (1999): Restrukturierungsprozesse einer Stadt-Umland-Ökonomie Veränderung der Wirtschaftsstruktur im Agglomerationsraum Basel. - In: Geographica Helvetica 54, 1: 7-17. KAUPP, A. (1999): Die Käferfauna begrünter Dächer im Stadtgebiet von Basel. - Regio Basiliensis 40, 2: 143-150.

Lenzin, H., Kohl, J., Mühlethaler, R., Odiet, M., Baumann, N. \& P. Nagel (2001): Verbreitung, Abundanz und Standorte ausgewählter Neophyten in der Stadt Basel (Schweiz). - Bauhinia (Zeitschrift der Basler Botanischen Gesellschaft) 15: 39-56.

LESER, H. (1997): Von der Biodiversität zur Landschaftsdiversität. Das Ende des disziplinären Ansatzes der Diversitätsproblematik. - In: ERdmann, K.-H. (Hrsg.): Internationaler Naturschutz. - Berlin, Heidelberg, New York: Springer Verlag: 145-175.

LESER, H. (1997): Landschaftsökologie. Ansatz, Modelle, Methodik, Anwendung. - 4. Auflage, UTB 521, Stuttgart: 1-644.

LESER, H. (2002a): Geographie und Transdisziplinarität - Fachwissenschaftliche Ansätze und ihr Standort heute. - Regio Basiliensis 43, 1:3-16.

LESER, H. (2002b): Natur und Landschaft zwischen endogenem Wandel und anthropogenen Veränderungen. Perspektiven eines «Neuen Naturschutzes». - In: BunDESAMT FÜr NATURSChUTZ (Hrsg.), bearbeitet von KarlHeinz Erdmann \& Christian Schell: Natur zwischen Wandel und Veränderung. Ursache, Wirkungen, Konsequenzen. - Berlin, Heidelberg, New York: 135-158.

LESER, H. \& H.-J. KLINK (Hrsg.) (1988): Handbuch und Kartieranleitung Geoökologische Karte 1:25 000 (KA GÖK 25). - Forschungen zur deutschen Landeskunde 228, Trier: 1-349.

LESER, H. \& P. NAGEL (1998): Landscape Diversity - a Holistic Approach.-In:BARTHLOTT,W.\& M.WinigER (eds): Biodiversity. A Challange for Development Research and Policy. - Berlin, Heidelberg, New York: 129-143.

Leser, H. \& D. Schaub (1995): Geoecosystems and Landscape Climate - The Approach to Biodiversity on Landscape Scale. - GAIA 4:212-220.

LESER, H. \& R. SCHNEIDER-SliwA (1999): Geographie - eine Einführung. - Das Geographische Seminar, Braunschweig: Westermann: 1-248.

Leser H., Meier-Zielinski, S., Prasuhn, V. ¿\& C. SeiBERTH (2002): Soil erosion cachtment areas of Northwestern Switzerland. Methodological conclusions from a 25-year research program. - In: Zeitschrift für Geomorphologie, N.F. 46: 35-60.

Luka, H., MargGi, W. \& P. NAgel (1997): Agonum nigrum Dejean, 1828, neu für die Schweiz. Ein Beitrag zur Gesamtverbreitung und Ökologie der Art (Coleoptera, Carabidae). - In: Mitteilungen der schweizerischen entomologischen Gesellschaft 70, 3-4:311-321. Marks, R., Müller, M.J., Leser, H. \& H.-J. KlinK 
(Hrsg.) (1989):Anleitung zur Bewertung des Leistungsvermögens des Landschaftshaushaltes (BA LVL). Forschungen zur deutschen Landeskunde 229, Trier: $1-222$.

MARXER, P. (2003): Oberflächenabfluss und Bodenerosion auf Brandflächen des Kastanienwaldgürtels der Südschweiz mit einer Anleitung zur Bewertung der post-fire Erosionsanfälligkeit (BA EroKaBr). - Physiogeographica, Basler Beiträge zur Physiogeographie 33: 1-217.

Mersch, J., Beauvais, M.-N. \& P. Nagel (1996): Induction of micronuclei in haemocytes and gill cells of zebra mussels, Dreissena polymorpha, exposed to clastogens. Mutation Research. - Genetic Toxicology Testing and Biomonitoring of Environmental or Occupational Exposure 371: 47-55.

Menz, M. (2001): Die Digitale Geoökologische Risikokarte. Prozessbasierte Raumgliederung am BlauenSüdhang im Nordwestschweizerischen Tafeljura. - Physiogeographica, Basler Beiträge zur Physiogeographie 29, Basel: 1-176.

MöSELER, B.M. \& R. MolendA (eds) (1999): Lebensraum Blockhalde. Zur Ökologie periglazialer Blockhalden im ausseralpinen Mitteleuropa. - Decheniana Beihefte, Bonn, 37: 1-170.

MüHlethaleR, R. \& P. NAGel (2001): Leafhoppers (Insecta:Auchenorrhyncha) of urban habitats of Basel. - In: Zotz, G. \& Ch. KöRner (eds): The Functional Importance of Biodiversity. - Verhandlungen der Gesellschaft für Ökologie 31:33.

NAGEL, P. (1995): Environmental Monitoring Handbook for Tsetse Control Operations. - Weikersheim: Margraf Verlag.

Nagel, P. (1997): New fossil paussids from Dominican amber with notes on the phylogenetic systematics of the paussine complex (Coleoptera, Carabidae). - In: Systematic Entomology 22, 4: 345-362.

NAGEL, P. (1999): Biogeographische Raumanalyse und Raumbewertung mit Tieren. - In: SCHNEIDER-SLIWA, R., Schaub, D. \& G. Gerold (Hrsg.): Angewandte Landschaftsökologie - Grundlagen und Methoden. Berlin, Heidelberg, New York: Springer Verlag: 397-425. NAGEL, P. (2000): Welche Insektenvielfalt wollen wir? Arten- und Naturschutzstrategien auf dem Prüfstand. - Mitteilungen der Deutschen Gesellschaft für allgemeine und angewandte Entomologie 12: 629-636.

NAGel，P. \& B. Baltes (1997): Erstnachweis von Capnioneura für das Saarland und den Hunsrück und Beiträge zur Habitatcharakteristik und Ökologie von C. mitis DESPAX, 1932 (Plecoptera: Capniidae). Lauterbornia (Zeitschrift für Faunistik und Floristik des Süßwassers) 28: 23-36.

Nagel, P., Saipunkaew, W. \& G. Smrekar (1998): Umweltüberwachung und ökologische Raumbewertung in der Stadt mit Hilfe von Organismen. - uni nova, Wissenschaftsmagazin der Universität Basel 82, September 1998: 39-42.
Nagel, P., Smrekar, G. \& D. Haag-Wackernagel (2001): Use of feral pigeon eggs for urban biomonitoring. - Fresenius Environmental Bulletin 10, 1: 18-25.

NeEF, E. (1967): Die theoretischen Grundlagen der Landschaftslehre. - Gotha, Leipzig: Haack VEB: 1-152.

NeEF, E. (1969): Der Stoffwechsel zwischen Gesellschaft und Natur als geographisches Problem. - Geographische Rundschau 21: 453-459.

NeEF, E. (1979): Analyse und Prognose von Nebenwirkungen gesellschaftlicher Aktivitäten im Naturraum. - Berlin, Abhandlungen der Sächsischen Akademie der Wissenschaften zu Leipzig, Math.-nat. Klasse, 50, 1: 1-70.

Ogermann, P. (1999): Mikrobielle Aktivität, Stoffumsatz und Nährstoffversorgung auf Magerrasenstandorten unterschiedlicher Vegetationszusammensetzung und Produktivität. - Physiogeographica, Basler Beiträge zur Physiogeographie 27, Basel:1-199.

Parlow, E. (1998a):Analyse von Stadtklima mit Methoden der Fernerkundung. - Geographische Rundschau 50, 2: 89-93.

PARLOW, E. (1998b) : Net radiation of urban areas. - In: Gudmandsen, P. (ed.): Future trends in remote sensing. - Rotterdam: Balkema Publishers: 221-226.

Parlow, E. (2000): Remotely sensed heat fluxes of urban areas. - In: DE DEAR, R.J., KALMA, J.D., OKE, T.R. and A. Auliciems (eds): Biometeorology and urban climatology at the turn of the millennium. - Selected papers from the conference ICB-ICUC'99, WMO/TD No. 1026: 523-528.

PARLOW, E. (2000): Snow runoff models using remotely sensed data. - In: Buchroithner, M. (ed.): Remote sensing for environmental data in Albania: a strategy for integrated management. - NATO Science Series 2, Environmental Security 72, Dordrecht: Kluwer Academic Publishers: 165-178.

Parlow, E. (2003): The Urban Heat Budget Derived from Satellite Data. - In: Geographica Helvetica 58, 2: 99-111.

Peveling, R. \& P. NAgel (2001): Locust and Tsetse Fly Control in Africa - Does Wildlife Pay the Bill for Food Security and Animal Health? - In: Johnston, JoHn J. (ed.): Pesticides and Wildlife. - ACS Symposium Series 771, Washington, DC: American Chemical Society (ACS): 82-108.

Peveling, R., Nagel, P. \& B. Sinsin (2003a): Conservation of Lama Forest - Role of Forest Plantations for the Viability of Natural Forests. - Gesellschaft für Tropenökologie, Tagungsband, 16. Jahrestagung in Rostock, Tropische Biodiversität im globalen Wandel, 19.-22. Februar 2003, Abstracts der Vorträge, 61 pp.

Peveling, R., Tingle, C., McWilliam, A., Nagel, P., Rasolomanana, H., Raholijaona, Rakotomianina, L., Ravoninjatovo, A., Dewhurst, C., Raveloson, A., Rafonomezana, S., Rahamefiarisoa, L.H. \& G. Gibson (2003b): Impact of locust control on harvester 
termites and endemic vertebrate predators in Madagascar. - In: Journal of Applied Ecology 40: 729-741.

Potschin, M. (2003): Nachhaltige Landschaftsentwicklung: Methodologische und methodische Ansätze. Habilitationsschrift Philosophisch-Naturwissenschaftliche Fakultät Universität Basel, 1-280 (mimeographed).

Prasuhn, V. (1991): Bodenerosionsformen und -prozesse auf tonreichen Böden des Basler Tafeljura (Raum Anwil, BL) und ihre Auswirkungen auf den Landschaftshaushalt. - Physiogeographica, Basler Beiträge zur Physiogeographie 16:1-372.

Rüetschi, D., Wüthrich,C., Wülser, R. \& P. Nagel (2001): Naturnahe Grundwasseranreicherung. Reinigungsmechanismen in den bewaldeten Wässerstellen der Langen Erlen (BS). - Zürich: gwa (Gas, Wasser, Abwasser) 81, 6:393-400.

Rüttimann, M. (2001): Boden-, Herbizid- und Nährstoffverluste durch Abschwemmung bei konservierender Bodenbearbeitung und Mulchsaat von Silomais. Vier bodenschonende Anbauverfahren im Vergleich. Physiogeographica, Basler Beiträge zur Physiogeographie 30, Basel, 1-241.

SAhli, B. \& R. Schneider-Sliwa (2004): Problèmes sociaux dans les ZUP (Zone à urbaniser en priorité) du Rhin Supérieur: l'exemple de Hautepierre à Strasbourg. - Bulletin, Association de Géographes Français, Paris (in press).

Scherer, D., Groebke, L. \& E. Parlow (2000): Photogrammetric analysis of a slush torrent in the Kärkevagge, Northern Sweden. - Nordic Hydrology 31, 4/5: 385-398.

Scherer, D., Gude, M., Gempeler, M. \& E. Parlow (1998): Atmospheric and hydrological boundary conditions for slushflow initiation due to snowmelt. - In: Annals of Glaciology 26: 377-380.

Scherer, D., Fehrenbach, U., Beha, H.-D. \& E. Parlow (1999): Improved Concepts and Methods in Analysis and Evaluation of the Urban Climate for Optimizing Urban Planning Processes. - In: Atmospheric Environment 33: 4185-4193.

SchneIder-SliwA, R. (Hrsg.) (2002): Städte im Umbruch - Globalisierung und Geographie in der Neustrukturierung von Berlin, Brüssel, Hanoi, Ho-Chi-MinhStadt, Hongkong, Jerusalem, Johannesburg, Moskau, St. Petersburg, Sarajewo und Wien. - Berlin: Reimer Verlag.

Schneider-Sliwa, R. (Hrsg.) (2003a): TriRhena. Eine Region ohne Grenzen? Basler Stadt- und Regionalforschung 22, Basel.

SCHNEIDER-SliwA, R. (2003b): Bedürfnisgerechte Stadtplanung - Bodenpflasterungen in der Innenstadt von Basel. - Basler Stadt- und Regionalforschung 24, Basel.

SchneIder-Sliwa, R. (2003c): Städtische Umwelt im Alter. - Nachfrage- und bedürfnisorientierte Untersuchungen zum Wohnumfeld und Quartiersgestaltung für eine altersgerechte Stadtplanung und Stadtpolitik. - Basler Stadt- und Regionalforschung 25, Basel.

SchNeIDER-SliwA, R. (Hrsg.) (2004): Fractures sociales et problématique urbaine en Suisse et en région rhénane méridionale. - Bulletin, Association de Géographes Français, Paris (in press).

Schneider-Sliwa, R. und A. Kampschulte (2002): Der Einkaufsstandort Bad Säckingen: Marktstudie zur Migros-Lohgerbe, Konsumentenverhalten und Entwicklungen im Einzelhandel. - Basler Stadt- und Regionalforschung 23, Basel.

Schneider-Sliwa, R., Kampschulte, A., Sandtner, M., Strassmann, R. \& R. Volman (2001): Wirtschaftsstruktur und Wirtschaftsdynamik der Nordwestschweiz. - In: Statistisches Amt des Kantons Basel-Stadt (Hrsg.): Stadt und Region 2, Basel.

Schneider-Sliwa, R., Kampschulte, A., Strassmann, R., Nommel, J.-U., SANDTner, M. \& C. WAFFEnSChmidT (1999): Bevölkerungsstruktur und Bevölkerungsdynamik beider Basel. - In: Statistisches AmT DES KANtons Basel-Stadt (Hrsg.): Stadt und Region 1, Basel. Schneider-Sliwa, R., Schaub, D. \& G. Gerold (Hrsg.) (1999):Angewandte Landschaftsökologie. Grundlagen und Methoden. Mit einer Einführung von Professor Dr. Klaus Töpfer, Exekutivdirektor UNEP/UNCHSHABITAT). - Berlin, Heidelberg, New York: Springer Verlag: 1-560.

Specht, I. (2002): La forêt de la Lama, Bénin -SIG basé sur Landsat 7. - Opuscula Biogeographica Basileensia 2, Institut für Natur-, Landschafts- und Umweltschutz (NLU) - Biogeographie, Institut für Meteorologie der Universität Basel, Faculté des Sciences Agronomiques, Université d'Abomey-Calavi, Bénin.

Stoddart, D.R. (1965): Geography and the Ecological Approach. The Ecosystem as a Geographical Principle and Method. - In: Geography 228, vol. L: 242-251.

Stolz, I., Nagel, P., Lomer, C. \& R. Peveling (2002): Susceptibility of the Hymenopteran Parasitoids Apoanagyrus (= Epidinocarsis) lopezi (Encyrtidae) and Phanerotoma sp. (Braconidae) to the Entomopathogenic Fungus Metarhizium anisopliae var. acridum (Deuteromycotina: Hyphomycetes). - Biocontrol Science and Technology 12: 349-360.

Strassmann, R., Frost, M. \& I. Brunner (2000): Veränderungen in der Branche «Dienstleistungen für Unternehmen» in der Nordwestschweiz. Eine wirtschaftsgeographische Untersuchung. - In: Regio Basiliensis 41, 1: 51-58.

Strassmann, R. (2002): Nordwestschweiz: Ein Grenzraum im Prozess der Globalisierung. - Revue Géographie de l'Est, Nancy, 42,1/2.

van Gorsel, E., Christen, A., Feigenwinter, C., Parlow, E. \& R. Vogt (2003): Daytime Turbulence Statistics above a Steep Forested Slope. - BoundaryLayer Meteorology (in press).

Vogt, R. \& C. Feigenwinter (2000): Structure of turbulent exchange above a forest. - In: DE DEAR, R.J., 
Kalma, J.D., OKe,T.R. \& A. Auliciems (eds): Biometeorology and urban climatology at the turn of the millennium. - Selected papers from the conference ICBICUC'99, WMO/TD No. 1026: 211-216.

WinIGER, M. (2002): Die «Mensch-Umwelt-Beziehungen» und die Geographie als «Brückenfach».- Diskussionspapier Rundgespräch Geographie II Bonn, 1-2, (mimeographed).

ZEPP, H. \& M.J. MÜLlER (Hrsg.) 1999: Landschaftsökologische Erfassungsstandards. Ein Methodenbuch. Forschungen zur deutschen Landeskunde 244, Flensburg: 1-535.

Prof.Dr.rer.nat. Dr.h.c. Hartmut Leser,Abteilung Physiogeographie und Landschaftsökologie, Prof. Dr. phil. Rita Schneider-Sliwa, Abteilung Humangeographie/ Stadt- und Regionalforschung, Geographisches Institut, Universität Basel, Klingelbergstr. 27, CH-4056 Basel.

Prof. Dr. phil. Peter Nagel, Institut für Natur-, Landschafts- und Umweltschutz NLU-Biogeographie, Universität Basel, St. Johanns-Vorstadt 10, CH-4056 Basel.

Prof. Dr. rer. nat. Eberhard Parlow, Institut für Meteorologie, Klimatologie und Fernerkundung, Universität Basel, Klingelbergstr. 27, 4056 Basel.
Prof. Dr.rer.nat. Christine Alewell, Institut für Umweltgeowissenschaften und Bodenkunde, Universität Basel, Bernoullistr. 30, CH-4056 Basel.

\section{Internet addresses}

Departement Geographie :

http://www.unibas.ch/geo/

Physiogeographie und Landschaftsökologie:

http://www.physiogeo.unibas.ch/

Humangeographie / Stadt- und Regionalforschung : http://www.humgeo.unibas.ch/

Meteorology, Climatology and Remote Sensing:

http://www.unibas.ch/geo/mcr/

NLU Biogeographie:

http://www.nlu.unibas.ch/

Umweltgeowissenschaften und Bodenkunde:

http://www.unibas.ch/environment 